\title{
Plant Remains from Shelby Mound (41CP71), Camp County, Texas
}

Leslie L. Bush

Heritage Research Center, Stephen F. Austin State University

Follow this and additional works at: https://scholarworks.sfasu.edu/ita

Part of the American Material Culture Commons, Archaeological Anthropology Commons, Environmental Studies Commons, Other American Studies Commons, Other Arts and Humanities Commons, Other History of Art, Architecture, and Archaeology Commons, and the United States History Commons

Tell us how this article helped you.

This Article is brought to you for free and open access by the Center for Regional Heritage Research at SFA ScholarWorks. It has been accepted for inclusion in Index of Texas Archaeology: Open Access Gray Literature from the Lone Star State by an authorized editor of SFA ScholarWorks. For more information, please contact cdsscholarworks@sfasu.edu. 
Plant Remains from Shelby Mound (41CP71), Camp County, Texas

Creative Commons License

(c) $($ ) $(9)$

This work is licensed under a Creative Commons Attribution-NonCommercial 4.0 International License 


\title{
Plant Remains from Shelby Mound (41CP71), Camp County, Texas
}

\author{
Leslie L. Bush
}

\section{INTRODUCTION}

Nine lots of botanical samples collected during 1988 and 1992 excavations at the Shelby Mound site (41CP71) were submitted for identification prior to their eventual curation at Stephen F. Austin State University. Some botanical samples from these excavations have been previously reported (Perttula and Nelson 2004). Excavations at Shelby Mound were conducted in a $10 \mathrm{x} 10 \mathrm{ft}$. unit divided into four $5 \mathrm{x} 5 \mathrm{ft}$. squares. Botanical samples were recovered using 1/4-inch screen. Shelby Mound, also known as the Tracy site and the Greasy Creek site, is a large Late Caddo village, community cemetery, and mound center. Most of the community cemetery at the site was destroyed by looters more than 30 years ago.

\section{ECOLOGICAL SETTING}

The Shelby Mound site is situated in southern Camp County, Texas. Mean annual precipitation in Camp County during the period 1951-1980 was 43.3 inches $(1100 \mathrm{~mm})$. Precipitation is distributed fairly evenly over the year, with a slight peak in the late spring. The frost-free season in Camp County today averages 238 days and runs from March 21 through November 14 (NFIC 1987:85-86).

Shelby Mound is located on the floodplain above Greasy Creek, which drains east into Big Cypress Creek, which in turn reaches the Red River via Caddo Lake. The site area lies at the northwestern edge of the Pineywoods ecological region, where the Pineywoods begins to grade into the Post Oak Savannah.

Upland forests at the northwestern edge of the Texas Pineywoods in pre-settlement times typically would have been shortleaf pine communities, where shortleaf pine (Pinus echinata) shared dominance with oaks (Quercus spp., both red and white groups) and hickories (several species, but frequently Carya texana) (Diggs et al. 2006:88-89). Coves and small streams supported mixed hardwood-loblolly pine communities. The lowlands associated with Big Cypress Creek would have supported flood-tolerant hardwoods such as sweetgum (Liquidambar styraciflua), beech (Fagus grandifolia), holly (Ilex spp.), maple (Acer spp.), and American hornbeam (Carpinus caroliniana) (Diggs et al. 2006:89-90, 100-101).

\section{VEGETATION RECONSTRUCTIONS}

Commercial harvesting has resulted in significant changes in Pineywoods vegetation since the mid$19^{\text {th }}$ century, with plantations of loblolly pine replacing shortleaf and longleaf stands. Nonetheless, modern equivalents exist for most prehistoric plant communities in East Texas (Diggs et al. 2006:87). Pollen studies indicate that use of the modern vegetation zones is appropriate for understanding the plants and attendant animal resources available to people during the first and second millennia. Weakly Bog, situated in the Post Oak Savannah vegetation region southwest of Camp County, provides some of the best data for vegetation reconstruction in the eastern half of Texas during the last 3,000 years (Bousman 1998). Pollen profiles from this bog indicate oak and later oak-hickory woodlands, suggesting that modern plant communities generally provide good analogs for Texas plant communities during the last 3,000 years. A recent study by Albert 
(2007) in southwest Upshur County provides supporting data. Some fluctuations in rainfall and temperature have taken place, however (Bousman 1998:204). Spikes in grass pollen at approximately 500 B.P. and 1500 B.P. suggest drier conditions during those times (Bousman 1998). Most notably, such changes would have altered the location of the Pineywoods-Post Oak Savannah edge (Bousman 1998:204).

\section{METHODS}

Materials from Shelby Mound arrived in the Macrobotanical Analysis laboratory in plastic bags and film containers, with no organic packing or labeling material such as cotton balls or paper. In the laboratory, all samples were subject to full radiocarbon protocols to retain suitability for radiocarbon dating. Samples were sorted on freshly cleaned glassware and handled only with latex gloves and metal forceps. The three samples that included small particles were placed on a No. $10(2 \mathrm{~mm})$ mesh to separate charcoal of identifiable size from sediment and charcoal flecks. Uncarbonized roots that did not fall through the mesh were removed, weighed, bagged, and labeled as "contamination." Residue that fell through the mesh was examined under a stereoscopic light microscope to ensure that it contained only wood charcoal consistent with that in the larger size fraction. Screens, sorting dishes, and scale pans were cleaned between samples. Contact with paper and other plant products was avoided. Only one sample was open at a time in the laboratory. Writing instruments used for data recording of samples were plastic mechanical pencils.

For each sample, 20 wood charcoal fragments were selected for identification at random from those larger than $2 \mathrm{~mm}$. When fewer than 20 fragments were present in a sample, identification was attempted for all. Fragments were snapped to reveal a clean transverse section and examined under a stereoscopic light microscope at 28-180 X magnification. When necessary, tangential or radial sections were examined for ray seriation, presence of spiral thickenings, types and sizes of inter-vessel pitting, and other minute characteristics that can only be seen at the higher magnifications of this range.

Botanical materials were identified to the lowest possible taxonomic level by comparison to materials in the Macrobotanical Analysis comparative collection and through the use of standard reference works (Core et al. 1979; Davis 1993; Hoadley 1990; InsideWood 2004; Martin and Barkley 2000; Musil 1963; Panshin and de Zeeuw 1980; Wheeler 2011). Due to the current (October 2013) federal government shut-down, botanical nomenclature follows that of the Native Plants Information Network (NPIN 2013) instead of the PLANTS Database (USDA, NRCS 2013).

\section{RESULTS}

Tables 1 and 2 show material from Shelby Mound carbon samples by count and weight, respectively. A small amount of non-plant material is included in these two tables. It should be noted that "daub" glosses any burned clay, with or without inclusions, from clay soil to house floors to construction material. Measurements of the 52 measurable corn cupules are given in Table 3.

\section{DISCUSSION}

\section{Archaeological versus modern plants}

Some uncarbonized plant parts were included in lots from Square D. The material consists of bark, pecan shell (Carya illinoinensis), and a grape seed fragment (Vitis spp.). Despite the relatively young age of the site $\left(15^{\text {th }}\right.$ to $17^{\text {th }}$ century A.D.), this material most likely did not survive from Late Caddo times in the humid climate of East Texas. In all except the driest areas of North America, uncarbonized plant material on open-air sites can be assumed to be of modern origin unless compelling evidence suggests otherwise 


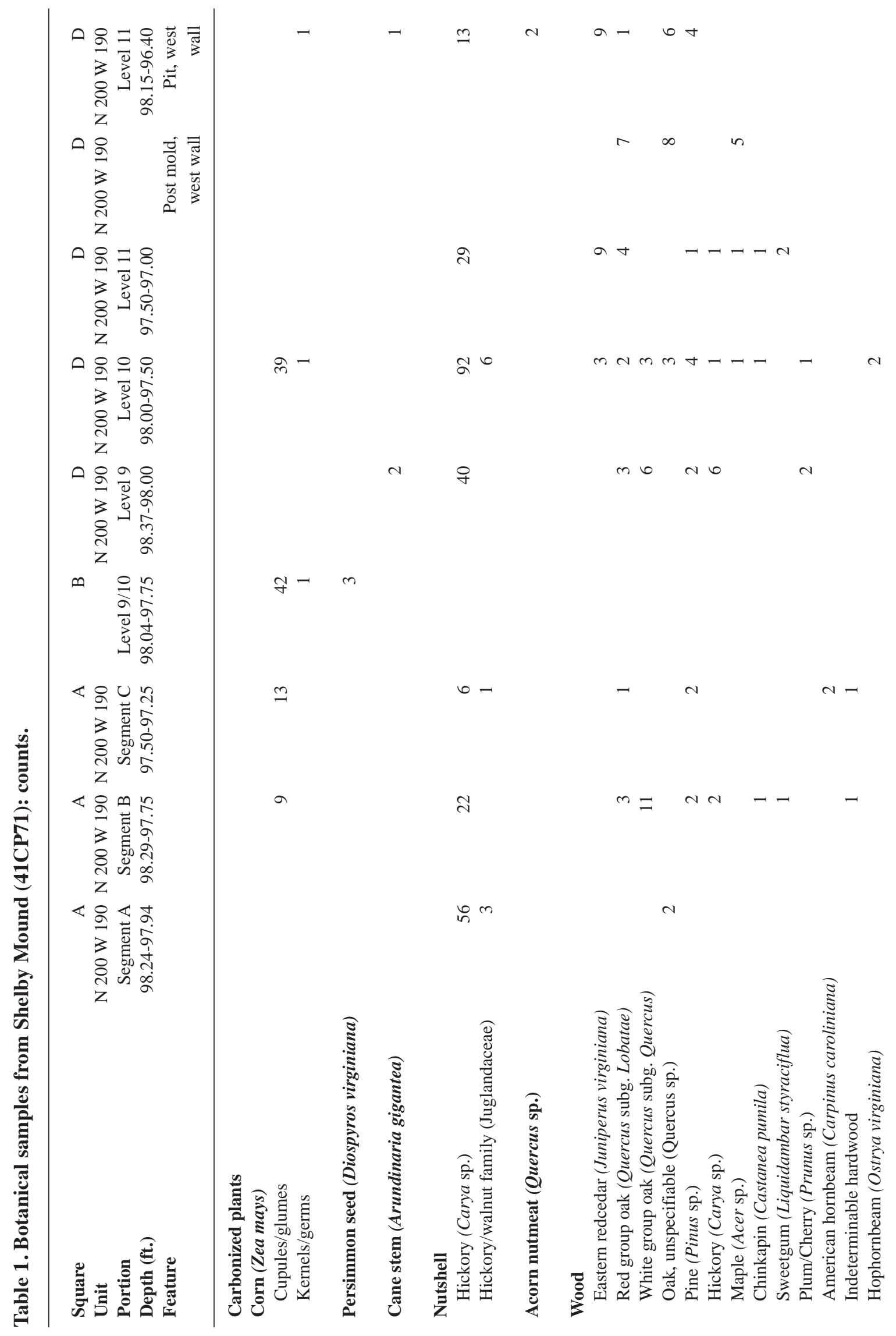




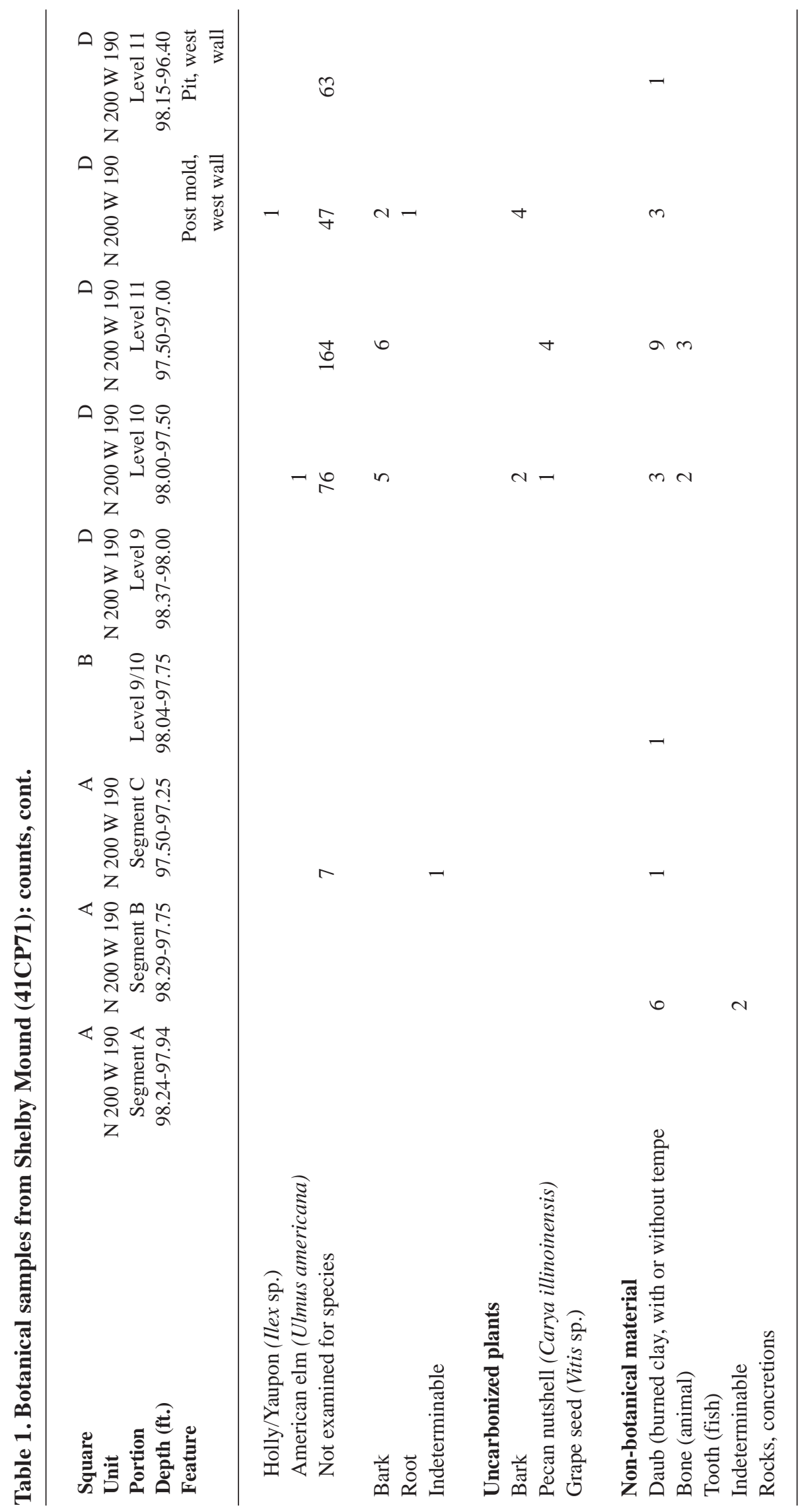




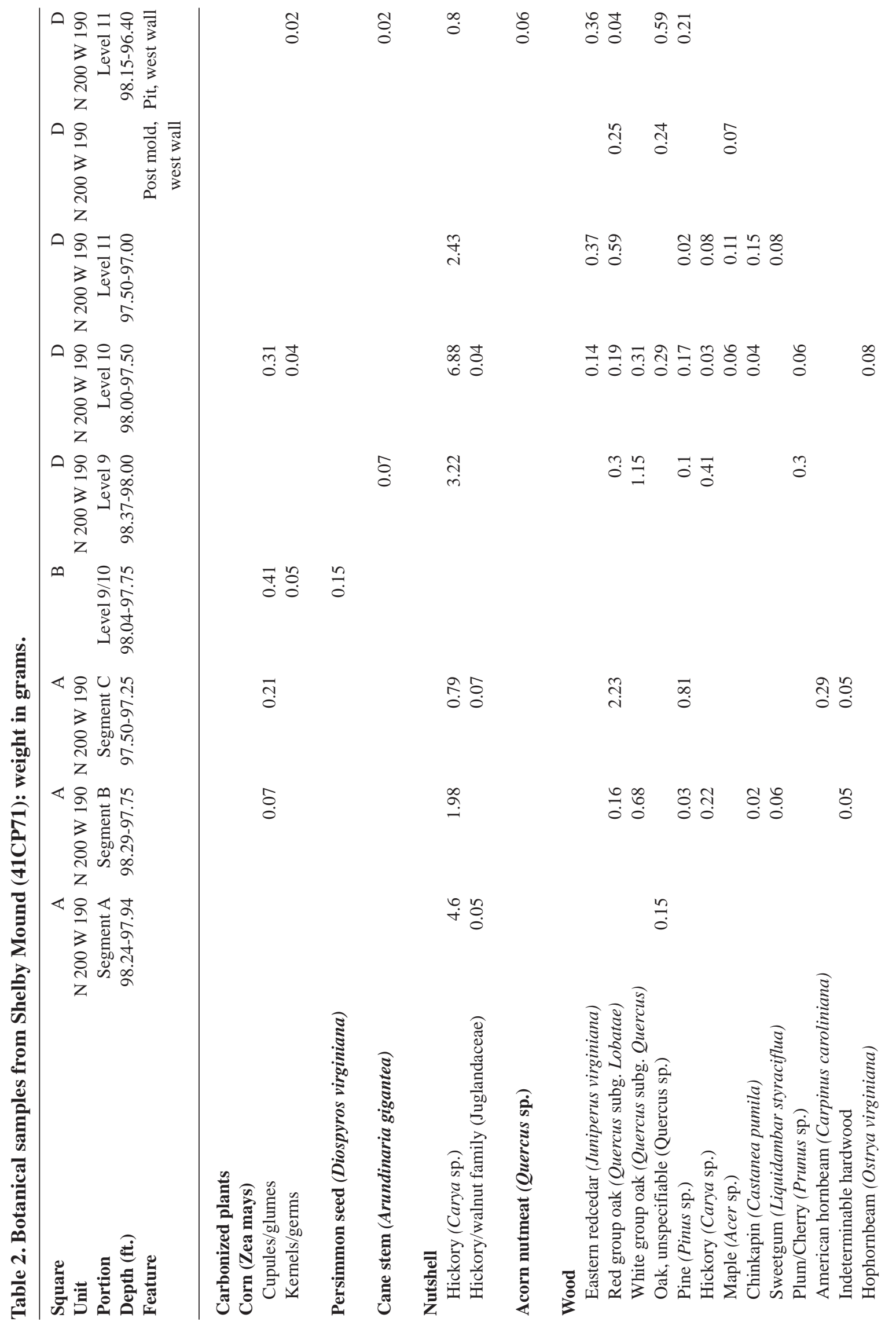




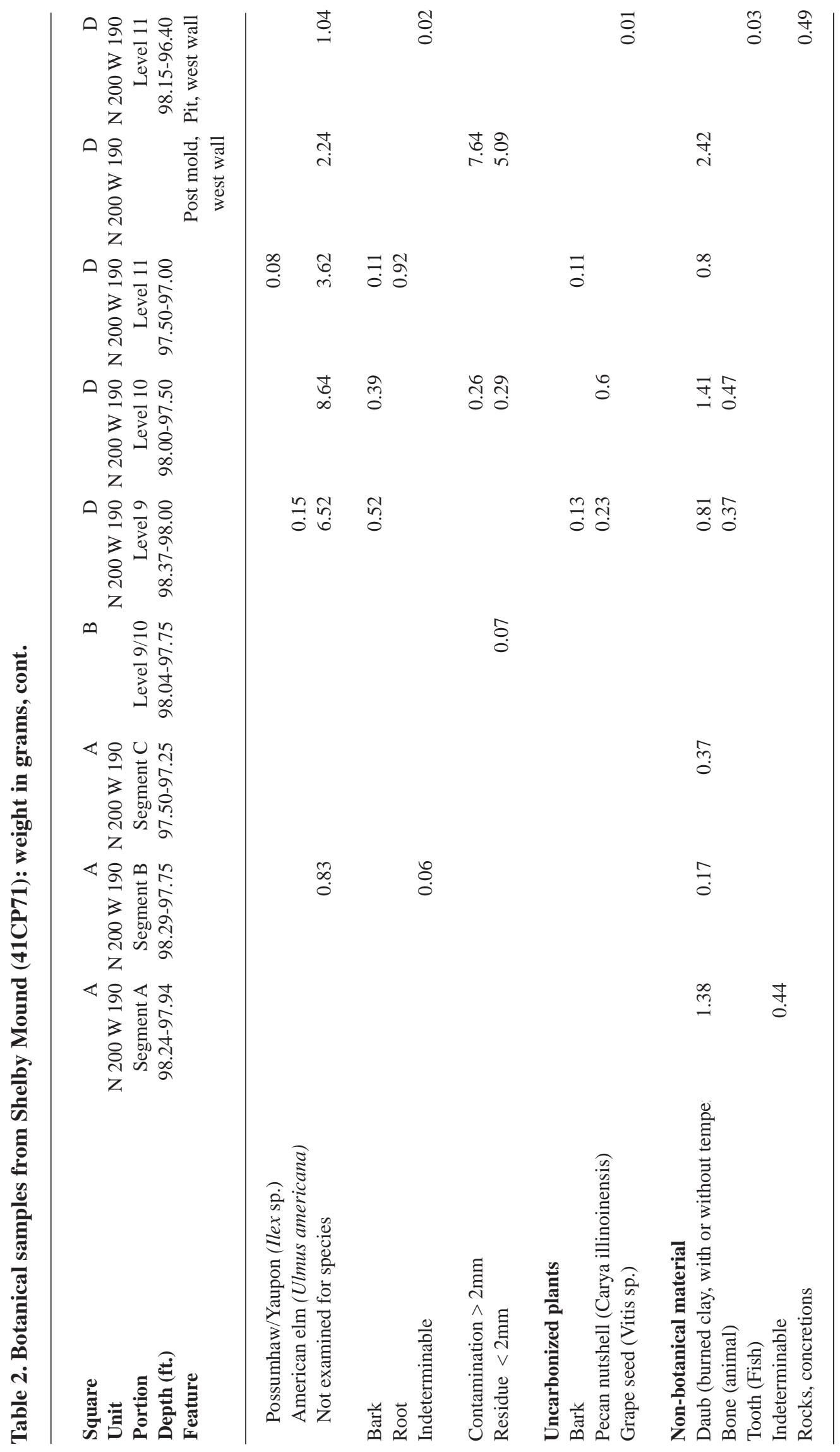


Table 3. Dimensions (in mm) of measurable corn cupules (Zea mays) from Shelby Mound (41CP71).

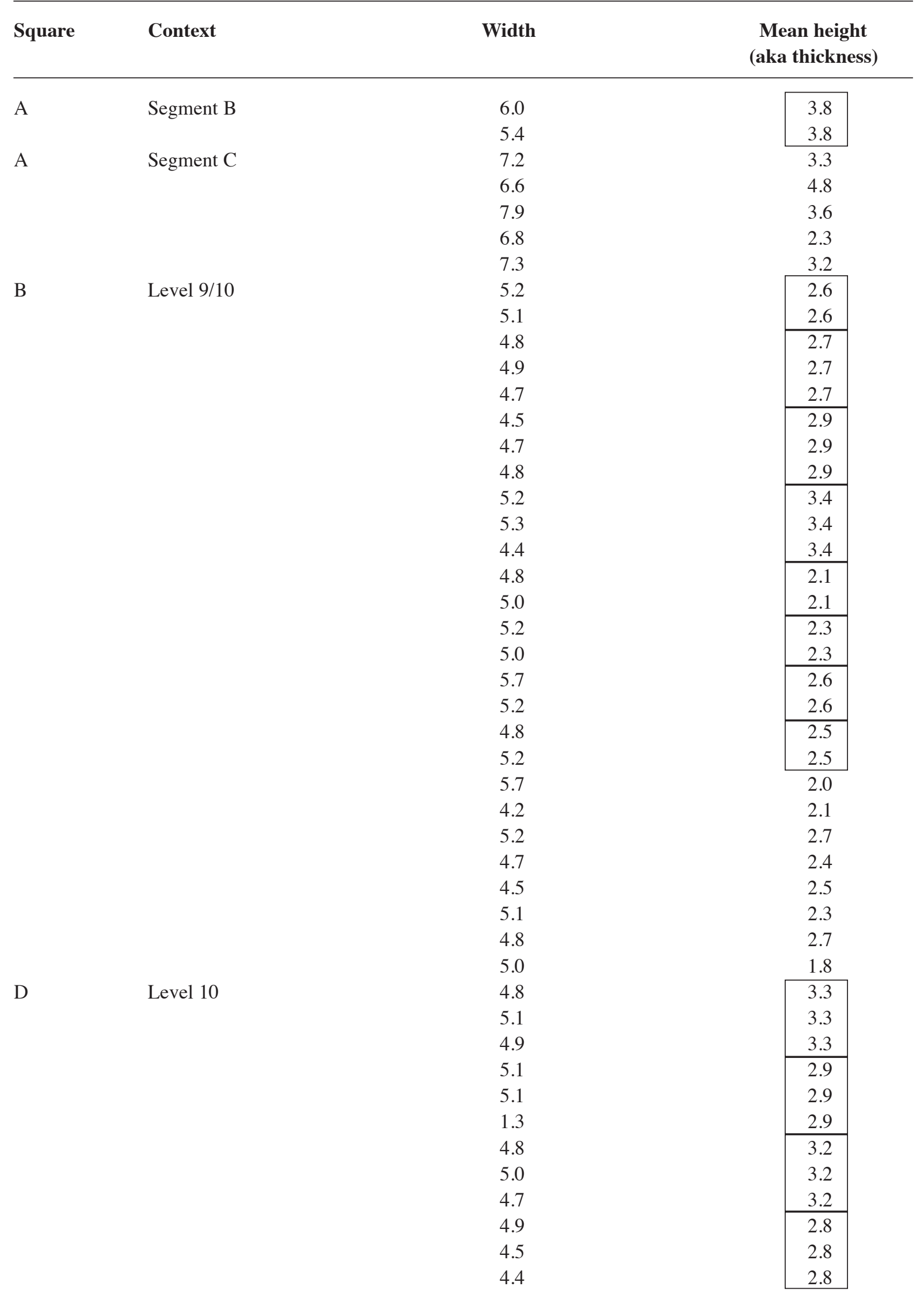


Table 3. Dimensions (in mm) of measurable corn cupules (Zea mays) from Shelby Mound (41CP71), cont.

\begin{tabular}{|c|c|c|c|}
\hline Square & Context & Width & $\begin{array}{l}\text { Mean height } \\
\text { (aka thickness) }\end{array}$ \\
\hline & & 3.5 & 2.6 \\
\hline & & 3.7 & 2.6 \\
\hline & & 4.0 & 2.9 \\
\hline & & 4.0 & 2.9 \\
\hline & & 3.8 & 2.9 \\
\hline Mean & & 5.0 & 2.8 \\
\hline
\end{tabular}

indicates cupules conjoined into a single rank (height column) or conjoined ranks of cupules (width colum).

(Lopinot and Brussell 1982; Miksicek 1987:231). The lack of carbonized pecan shell and grape pits support the inference that uncarbonized plants have different origins than the carbonized plants.

\section{Corn (Zea mays)}

Three nearly-whole corn kernels were recovered from Squares B and D. All three squares yielded corn cupules. Many cupules were conjoined in single-rowed ranks, and two ranks from Square D were joined into a short double row. The angle between the conjoined cupules is approximately 80 degrees, suggesting an eight or 10-rowed ear. Many cupules had glumes attached, usually the lower but sometimes the upper. Fifty-two cupules were complete enough for measurement of width and height (Table 3). When cupules were conjoined into ranks, height measurements were taken on the entire rank and divided by the number of cupules in the rank for better accuracy. As indicated in Table 4, the cupule measurements from Shelby Mound are consistent with those from other Caddo sites.

\section{Wild plants}

Three fragments of persimmon seeds (Diospyros virginiana) were recovered from Square B. Fragments of river cane (Arundinaria gigantea) were found in Level 9, Square D. Nutshell was found in all but two of the samples. Most of it was clearly thick-shelled hickory (Carya spp.; n=258), but 10 specimens could be identified only as hickory/walnut family (Juglandaceae).

\section{Wood charcoal}

A total of 508 fragments of wood charcoal weighing $34.66 \mathrm{~g}$ were recovered in the samples. One hundred and thirty fragments were examined for species identification, of which 128 could be identified to the genus or species. Forty-six percent of the wood charcoal was oak (Quercus spp.; $\mathrm{n}=60$ ), with white group and red group oaks represented equally. After oak, eastern red cedar (Juniperus virginiana, also called juniper) was the next most common wood. It was present in three samples from Square D. Red cedar is present but not terribly common in East Texas. Ritual or symbolic structures made from red cedar wood are known from the American Bottom area (Simon 2002), and Bobby Gonzalez describes uses of cedar in contemporary Caddo mortuary traditions (Gonzalez 2005:57-59). At Shelby Mound, two red cedar poles were preserved with one of the (looted) burials (Perttula 2009). The red cedar fragments in these Shelby Mound samples likely also reflects use in ceremonial contexts. 
Table 4. Mean corn cupule (Zea mays) measurements (in $\mathbf{m m}$ ) from selected Caddo sites (measurements in $\mathbf{m m}$ ).

\begin{tabular}{lllll}
\hline Site & $\begin{array}{l}\text { Cupule } \\
\text { width }\end{array}$ & $\begin{array}{l}\text { Cupule } \\
\text { thickness } \\
\text { (height) }\end{array}$ & $\begin{array}{l}\text { Number of } \\
\text { cupules } \\
\text { measured }\end{array}$ & Reference \\
\hline Oak Hill Village (41RK214) Fea. 86* & 4.8 & 3.1 & $\sim 10220$ & Elson et al. 2004 \\
41PN175 & 4.9 & 2.3 & 39 & Bush 2013 \\
W. A. Ford (41TT852) & 5.0 & 2.9 & 10 & Bush 2011 \\
Shelby Mound (41CP71) & 5.0 & 2.8 & 52 & this article \\
Pine Tree Mound (41HS15) & 5.3 & 2.3 & 106 & Bush 2012 \\
Stallings Ranch (41LR297) & 5.4 & 3.1 & 35 & Bush 2008 \\
Henry M. (41NA60) & 6.1 & 1.9 & 20 & Perttula et al. 2010 \\
Ramos Creek (34MC1030), all others & 6.5 & 3.1 & 87 & Dowd n.d. \\
Winding Stair (3MN496) & 6.5 & $\mathrm{n} / \mathrm{a}$ & 256 & Williams 2000 \\
Sha'chahdínnih (41MR211)** & 7.2 & 2.8 & 229 & Goldborer 2002 \\
\hline
\end{tabular}

Note: all cupules carbonized; includes whole cobs, cupules attached in ranks, and loose cupules

*Mean of measurements given in Table 91. Number of cupules estimated from 108 measurable cobs, row numbers distributed as given in Table 91, assuming 10 measurable cupules per rank.

** Mean of measurements given in Appendix Tables 3A-D.

\section{PREVIOUS SAMPLES FROM SHELBY MOUND}

Examination of other botanical samples from the same excavations yielded many of the same plants recovered here. One additional species of wood was identified (Salix spp.; willow), and a domestic bean (Phaseolus vulgaris) was also found (Perttula and Nelson 2004).

\section{REFERENCES CITED}

Albert, B. M.

2007 Climate, Fire, and Land-use History in the Oak-Pine-Hickory Forests of Northeast Texas during the past 3500 Years. Castanea 72(2):82-91.

Bousman, C. B.

1998 Paleoenvironmental Change in Central Texas: The Palynological Evidence. Plains Anthropologist 43(164):201-219.

Bush, L. L.

2008 Macrobotanical Remains from the 2005 and 2006 Texas Archeological Society Field Schools at the Gene and Ruth Ann Stallings Site (41LR297). 30 pp. Manuscript submitted to the Texas Archeological Society, San Antonio. June 28, 2008.

2011 Plant Remains from the Mount Pleasant Bypass Project: Three Caddo Hamlets on the Post Oak Savannah. Manuscript submitted to Prewitt and Associates, Inc., Austin. April 11, 2011.

2012 Macrobotanical Remains. In Archeology of the Nadaco Caddo: The View from the Pine Tree Mound Site (41HS15), Harrison County, Texas, edited by R. C. Fields and E. F. Gadus, pp. 728-772. 2 Vols. Reports of Investigations No. 164. Prewitt and Associates, Inc., Austin.

2013 Plant Remains from Site 41PN175, Panola County, Texas. Manuscript submitted to Geo-Marine, Inc., Plano. July 26, 2013. 
Core, H. A., W. A. Cote, and A. C. Day

1979 Wood Structure and Identification. 2nd Edition. Syracuse University Press, Syracuse, New York.

Davis, L. W.

1993 Weed Seeds of the Great Plains: A Handbook for Identification. University Press of Kansas, Lawrence.

Diggs Jr., G. M., B. L. Lipscomb, M. D. Reed and R. J. O’Kennon

2006 Illustrated Flora of East Texas, Volume One: Introduction, Pteridophytes, Gymnosperms, and Monocotyledons Sida, Botanical Miscellany, No. 26. Botanical Research Institute of Texas, Fort Worth.

Dowd, E. L.

n.d. Mountain Fork Archaeology: A View from the Ramos Creek Site (34MC1030). Sam Noble Museum of Natural History, Norman, Oklahoma, in preparation.

Elson, K. M., C. Smith and T. K. Perttula

2004 Additional Maize Studies. In The Oak Hill Village Site (41RK214), Rusk County, Texas, by R. Rogers and T. K. Perttula, pp. 323-335. Document No. 030083. PBS\&J, Austin.

Goldborer, S. E.

2002 Macrobotanical Evidence of Subsistence at Timber Hill. In Finding Sha'chahdinnih (Timber Hill): The Last Village of the Kadohadacho in the Caddo Homeland, by M. L. Parsons, J. E. Bruseth, J. Bagur, S. E. Goldborer, and C. McCrocklin, pp. 81-86. Archeological Reports Series No. 3. Texas Historical Commission, Austin.

Gonzalez, B.

2005 Caddo Tribal Religious Burial Ceremonies Beyond Archeology. In A Rediscovering of Caddo Heritage: The W. T. Scott Collection at the American Museum of Natural History and Other Caddo Collections from Arkansas and Louisiana, by B. Gonzalez, R. Cast, T. K. Perttula, and B. Nelson, pp. 55-59. Caddo Nation of Oklahoma, Historic Preservation Program, Binger, Oklahoma.

Hoadley, R. B.

1990 Identifying Wood: Accurate Results with Simple Tools. The Taunton Press, Newtown, Connecticut.

InsideWood

2004-onwards Published on the Internet. http://insidewood.lib.ncsu.edu/search.

Lopinot, N. H. and D. E. Brussell

1982 Assessing Uncarbonized Seeds from Open-air Sites in Mesic Environments: An Example from Southern Illinois. Journal of Archaeological Science 9:95-108.

Martin, A. C. and W. D. Barkley

2000 Seed Identification Manual. The Blackburn Press, Caldwell, New Jersey.

Miksicek, C. H.

1987 Formation Processes of the Archaeobotanical Record. In Advances in Archaeological Method and Theory, Vol. 10, edited by M. B. Schiffer, pp. 211-247. Academic Press, Inc., New York.

Musil, A. F.

1963 Identification of Crop and Weed Seeds Agriculture Handbook No. 219. U.S. Department of Agriculture, Washington, D.C.

NFIC (Natural Fibers Information Center)

1987 The Climates of Texas Counties. Natural Fibers Information Center, The University of Texas at Austin, in cooperation with the Office of the State Climatologist, Texas A\&M University, Austin.

NPIN (Native Plants Information Network)

2013 Native Plant Database. http://wildflower.org/plants. Lady Bird Johnson Wildflower Center, Austin, Texas, 78739. Accessed 10/10/2013. 
Panshin, A. J. and C. de Zeeuw

1980 Textbook of Wood Technology: Structure, Identification, Properties, and Uses of the Commercial Woods of the United States and Canada. Fourth ed. McGraw-Hill Book Company, New York.

Perttula, T. K.

2009 A Radiocarbon Date from a Cedar Pole in a Special Caddo Burial Feature at the Shelby Mound site (41CP71). Texas Archeology (Newsletter of the Texas Archeological Society) 53(1):20-21.

Perttula, T. K., L. L. Bush, L. Schniebs, T. Middlebrook, and P. S. Marceaux

2010 An Early Historic Farmstead at the Henry M. Site (41NA60) in Nacogdoches County, Texas. Stephen F. Austin State University Press, Nacogdoches.

Perttula, T. K. and B. Nelson

2004 Archeological Investigations at the Shelby Site (41CP71) on Greasy Creek, Camp County, Texas. Special Publication No. 5. Friends of Northeast Texas Archaeology, Pittsburg and Austin.

Simon, M. L.

2002 Red Cedar, White Oak, and Bluestem Grass: The Colors of Mississippian Construction. Mid-Continental Journal of Archaeology 27(2):273-308.

USDA, NRCS (United States Department of Agriculture, Natural Resources Conservation Service)

2013 The PLANTS Database. http://plants.usda.gov. National Plant Data Team, Greensboro, NC 27401-4901.

Wheeler, E. A.

2011 InsideWood - A Web Resource for Hardwood Anatomy. IAWA Journal 32(2):199-211.

Williams, M. L.

2000 Ethnobotanical Analysis (Winding Stair and Bug Spot). In Forest Farmsteads: A Millennium of Human Occupation at Winding Stair in the Ouachita Mountains, edited by A. M. Early, pp. 111-122. Research Series 57. Arkansas Archeological Survey, Fayetteville. 